УДК 368.1:[343.37:336.228.34] (477)

JEL G22, G28, F52

DOI: https://doi.org/10.35774/visnyk2020.03.199

\title{
Сергій лєОНОВ,
}

доктор економічних наук, професор, професор кафедри економічної кібернетики,

Сумський державний університет,

вул. Римського-Корсакова, 2, м. Суми, 40007, Україна,

e-mail: s.lieonov@uabs.sumdu.edu.ua

ORCID iD: https://orcid.org/0000-0001-5639-3008

\section{Ольга КУЗЬМЕНКО,}

доктор економічних наук, професор, професор кафедри економічної кібернетики,

Сумський державний університет,

вул. Римського-Корсакова, 2, м. Суми, 40007, Україна,

e-mail: o.kuzmenko@uabs.sumdu.edu.ua

ORCID iD: https://orcid.org/0000-0001-8520-2266

\section{Сергій МИНЕНКО,}

аспірант кафедри економічної кібернетики,

Сумський державний університет,

вул. Римського-Корсакова, 2, м. Суми, 40007, Україна,

e-mail: s.minenko@uabs.sumdu.edu.ua

ORCID iD: https://orcid.org/0000-0003-3998-9031

\section{Олексій ЛюЛЬОВ,}

доктор економічних наук, доцент, завідувач кафедри маркетингу,

Сумський державний університет,

вул. Римського-Корсакова, 2, м. Суми, 40007, Україна,

e-mail: alex_lyulev@econ.sumdu.edu.ua

ORCID iD: https://orcid.org/0000-0002-4865-7306

\section{ВИКОРИСТАННЯ ПОСЛУГ СТРАХОВИХ КОМПАНІЙ 3 МЕТОЮ ЛЕГАЛІЗАЦІЇ КРИМІНАЛЬНИХ ДОХОДІВ ЕКОНОМІЧНИХ АГЕНТІВ ТА УХИЛЕННЯ ВІД СПЛАТИ ПОДАТКІВ ПІДПРИЄМСТВАМИ}

Лєонов С., Кузьменко О., Миненко С., Люльов О. Використання послуг страхових компаній з метою легалізації кримінальних доходів економічних агентів та ухилення від сплати податків підприємствами. Вісник Тернопільського національного економічного університету. 2020. Вип. 3. C. 199-210. DOI: https://doi.org/10.35774/ visnyk2020.03.199

(C) Сергій Лєонов, Ольга Кузьменко, Сергій Миненко, Олексій Люльов, 2020. 
Lyeonov, S., Kuzmenko, O., Mynenko, S., Lyulyov, O. (2020). Vykorystannia posluh strakhovykh kompanii z metoiu lehalizatsii kryminalnykh dokhodiv ekonomichnykh ahentiv ta ukhylennia vid splaty podatkiv pidpryiemstvamy [Using of insurance companies 'services for the purpose of legalization of criminal income of economic agents and avoidance of taxation]. The Herald of Ternopil National Economic University, Vol. 3. P. 199- 210. DOI: https://doi.org/10.35774/visnyk2020.03.199

\section{Анотація}

Вступ. Забезпечення стабільного функціонування ринку фінансових послуг $\epsilon$ одним з важливих напрямів реалізації державної економічної політики. Без використання послуг фрінансових посередників неможливе фрункціонування економіки. Злочинці в свою чергу користуються слабкими місиями фінансової системи країни для власного незаконного збагачення чи досягнення інших злочинних інтересів. Легалізуючи кошти, отримані незаконним шляхом злочинці дестабілізують фінансову систему країни та розширюють розмір тіньової економіки.

Метою статті $\epsilon$ характеристика можливості використання послуа страхових компаній з метою легалізації кримінальних доходів економічних агентів та ухилення від сплати податків підприємствами.

Результати. В статті визначено ризик використання послуг страхових компаній для легалізації доходів, отриманих незаконним шляхом та місце даних послуг в на ринку. В ході дослідження було комплексно розглянуто можливість використання шахраями послуг страхових компаній для легалізації незаконних доходів економічних агентів та ухилення від сплати податків підприємствами. Були наведені приклади легалізації незаконних доходів через послуги страхових компаній. Визначено три основні групи послуг страхових компаній: загальне страхування, страхування життя (пенсійне страхування) та перестрахування. Визначено основні ризики, пов'язані з легалізацією незаконних доходів притаманні кожні групі послуг. Узагальнюючи проведений аналіз було визначено загальні рекомендації для страхових компаній для запобігання легалізації незаконних доходів через їх послуги.

Перспективи подальших досліджень. Перспективами подальших досліджень $\epsilon$ кількісна характеристика ризику легалізації кримінальних доходів економічних агентів та ухилення від сплати податків для кожної групи послуг, так як вони мають власні специфрічні особливості.

Ключові слова: легалізація незаконних доходів; послуги страхових компаній; страхування; перестрахування; ухилення від сплати податків.

Формули:0, рис.: 1, табл.: 0, бібл.: 22

\section{Abstract}

\section{Serhii LYEONOV, Olha KUZMENKO, Serhii MYNENKO, Oleksii LYULYOV}

USING OF INSURANCE COMPANIES 'SERVICES FOR THE PURPOSE OF LEGALIZATION OF CRIMINAL INCOME OF ECONOMIC AGENTS AND AVOIDANCE OF TAXATION

Annotation. Providing the stable and continuous functioning of the financial services market is one of the important areas of state economic policy. Without the use of financial 
intermediaries, the economy cannot function. Criminals, in turn, use the weaknesses of the country's financial system for their own illicit enrichment or the pursuit of other criminal interests. By laundering illegally obtained money, criminals destabilize the country's financial system and expand the size of the shadow economy.

The purpose of the article is to characterize the possibility of using the services of insurance companies in order to legalize the criminal income of economic agents and tax evasion by enterprises.

Results. The article identifies the risk of using the services of insurance companies to legalize illegally obtained income and the place of these services in the market. The study comprehensively considered the possibility of fraudsters using the services of insurance companies to launder the illegal income of economic agents and tax evasion by enterprises. Examples of legalization of illegal income through the services of insurance companies were given. There are three main groups of insurance companies' services: general insurance, life insurance (pension or insurance for investments), and reinsurance. The main risks associated with money laundering are inherent in each group of services. Summarizing the analysis, general recommendations for insurance companies to prevent money laundering through their services were identified.

The prospects for further research. The Prospects for further research are the quantitative characterization of the risk of legalization of criminal income of economic agents and tax evasion for each group of services, as they have their own specific features.

Keywords: legalization of illegal income; insurance company services; insurance; reinsurance; tax evasion.

Formulas: 0 , fig.: 1 , tabl.: 0 , bibl.: 20

Постановка проблеми в загальному вигляді. Поширення глобальних інтеграційних процесів у світовій економіці й особливо у фрінансовому просторі останнім часом створює сприятливі умови для кримінальних структур в частині легалізації доходів, отриманих незаконним шляхом. Водночас зі зростанням кількості посередників на ринку фрінансових послуг, які використовують сучасні інформаційні технології, зростають способи та засоби відмивання незаконних коштів. Фінансові технології дають змогу у лічені години укладати договори, надавати фінансові послуги, передавати гроші з одного кінця світу на інший. На передовій запровадження інновацій у фінансових послугах перебувають саме банки та страхові компанії. Онлайн доступ до фрінансових послуг мають майже всі жителі розвинених країн світу. Дані процеси видозмінюють способи ідентифрікації клієнтів і ведення бізнесу у фінансовій сфрері $[1,2]$.

Шахраї використовують вразливості фрінансових інновацій. Наприклад, для створення системи юридичних осіб при легалізації незаконних доходів на стадії розшарування коштів можна скористатись функцією онлайн реєстрації юридичних осіб. Також зловмисники можуть в різні способи отримати доступ до особистого кабінету клієнтів, чи навіть функціонувати від імені вигаданої особи і таким чином здійснювати операції з легалізації незаконних доходів.

Зазначені особливості сучасного розвитку фінансових послуг та технологій формують нові виклики для фінансових установ і державних регуляторів у сфері фрінансових послуг. 
Аналіз останніх досліджень та публікацій. Над даною тематикою працювала низка вітчизняних та зарубіжних вчених. Дане питання розглядалось вченими з різних сторін. Ризик легалізації кримінальних доходів через послуги страхових компаній розглядали М. Каміллері [3], С. Дмитров і Т. Медвідь [4], Т. Веризубова та В. Левченко [5]. 3 точки зору детінізації та підвищення економічної стабільності національної економіки дане питання досліджували М.А. Субе та А. Бойко [6], Л. Сінєвічене, О. Шкарупа та Л. Сисоєва [7], Т. Кобзієва і Т. Шлапко [8], М. Паліенко та О. Люльов [9]. 3 боку оподаткування підприємств - Г. Яровенко, Т. Басенко [10], Д. Марченко [11] та О. Люльова [12].

Формулювання цілей статті (постановка завдання). Метою статті $є$ характеристика можливості використання послуг страхових компаній для легалізації кримінальних доходів економічних агентів і ухилення від сплати податків підприємствами.

Виклад основного матеріалу дослідження. Враховуючи специфіку операцій, які надають фінансові посередники відрізняється й рівень їх залучення до процесів відмивання доходів, отриманих незаконним шляхом. Найвищий рівень залучення фінансових установ характерний для банків. Наприклад, за два квартали 2020 року Державною службою фінансового моніторингу взято на облік 3962557 повідомлень про фінансові операції, що підлягають фрінансовому моніторингу. 3 них 3909459 повідомлення надійшло від банківських установ, 37182 від небанківських фінансових установ та організацій, а також 247 повідомлення від спеціально визначених суб'єктів первинного фінансового моніторингу [13].

Водночас, справедливо констатувати, що серед небанківських фрінансових установ найбільш популярними серед шахраїв $€$ операції страхових компаній. В Україні ринок страхових послуг є відносно молодим та динамічно розвиваючим. За даними Нацкомфінпослуг лише у I кварталі 2020 року обсяг валових страхових премій складав 11,549 млрд. грн., а страхових виплат - 3,750 млрд. грн [14]. За 2019 рік в цілому обсяг валових страхових премій склав 53,001 млрд. грн., а страхових виплат 14,338 млрд. грн. відповідно $[15,16]$. Низький рівень контролю за операціями страховиків, значна кількість страхових компаній в Україні, можливість використання однією компанією відразу трьох інструментів розшарування ризику: страхування життя, ризикове страхування та перестрахування робить привабливим страховий сектор для суб'єктів відмивання грошей [17].

Отже, розглянемо їх більш детально. Розглядаючи ризик легалізації доходів при страхуванні життя виділимо наступні операції:

1. Придбання полісу одної премії. За такого типу страхування життя страхувальник сплачує страховику одноразову грошову суму в обмін на гарантію отримання виплати у разі дожиття за договором або у випадку смерті. Даний спосіб дає змогу позбутись в одночас великої кількості грошей, а через певний час отримати страхову виплату у вигляді «чистих» грошей.

2. Отримання аннуїтету. Відмивання грошей здійснюється при одержанні суб'єктом легалізації страхових виплат, після сплати страхових премій «брудними» грошима.

3. Скупка полісів страхування з великою кількістю невеликих регулярних премій з метою уникнення зайвої уваги, так як фінансовий моніторинг зазвичай цікавлять великі суми грошей. 
4. Навмисна переплата премій чи повернення премій страховими компаніями безпосередньо на банківський рахунок страхувальника.

5. Заміна бенефеціара. Наразі законодавчо не обмежена кількість вигодонабувачів від страхування життя. Також в процесі $€$ можливість змінити бенефіціара. Дана вразливість веде до розшарування грошей при отриманні страхових виплат [16].

6. Повернення полісу. Суб'єкти легалізації можуть повернути свої поліси зі збитком, щоб повернути свої депоновані гроші.

7. Кредити по полісу. Шахраї можуть брати позики за полісом страхування життя. Позики за полісом не мають жорстких перевірок фрінансового моніторингу і не потребують погашення. В такому разі вартість позики та відсотки будуть вирахувані 3 виплати на випадок смерті. Також поліси можуть бути забезпеченням кредитів.

8. Вторинний ринок життя: клієнти з поганим здоров'ям можуть продати свій поліс злочинній третій стороні. Це створює проблеми страховим компаніям, так як вони повинні проводити ідентифікацію нового власника, що часто буває складно або неможливо [18].

Страхуванню життя більше притаманна ризиковість діяльності щодо легалізації доходів, отриманих незаконним шляхом, ніж загальному страхуванню. Основна причина цього - інвестиційний характер страхування життя. Так, премія яку вносить страхувальник у загальному страхуванні ризиків пов'язана з конкретним видом ризику та видом ризику, що покриває поліс. Як правило, таке страхування обмежується потенційним поверненням не закінченої або невикористаної премії. Нежитлові товари не мають накопиченої грошової або інвестиційної вартості. Але зазначені обмеження не виключають ризик використання даного виду страхування для відмивання незаконних доходів. При цьому, загальне страхування дає змогу занизити базу оподаткування підприємства і таким чином перевести частину доходу в тінь.

Прикладами використання загального страхування може бути:

- використання коштів, отриманих незаконним шляхом для виплат премій або значна переплата премій з наступним запитом на повернення коштів як на повну, так і на переплачену суму;

- страхування рухомих чи нерухомих активів на незаконні кошти, подальше умисне пошкодження активу й отримання відшкодування за полісом [19];

- використання укладених договорів псевдострахування. За такого виду страхування підприємства прагнуть «уникнути» ризиків, ймовірність настання яких мінімальна або майже нульова. Після укладення такого договору, частина сплаченої страхової суми пов'язаними особами у страховій компанії конвертується у готівку і повертається керівникам підприємства. Окрім того, дана схема застосовується підприємствами для ухилення від оподаткування шляхом зменшення податкового навантаження [20];

-використання фріктивного страхування фінансових ризиків. В даному разі шахраї користуються простотою у підробленні страхових випадків при фінансових ризиках. Наприклад, якщо було застраховано не надходження коштів за договором поставки та такий страховий випадок настає протягом дуже короткого проміжку часу після укладення договору. 


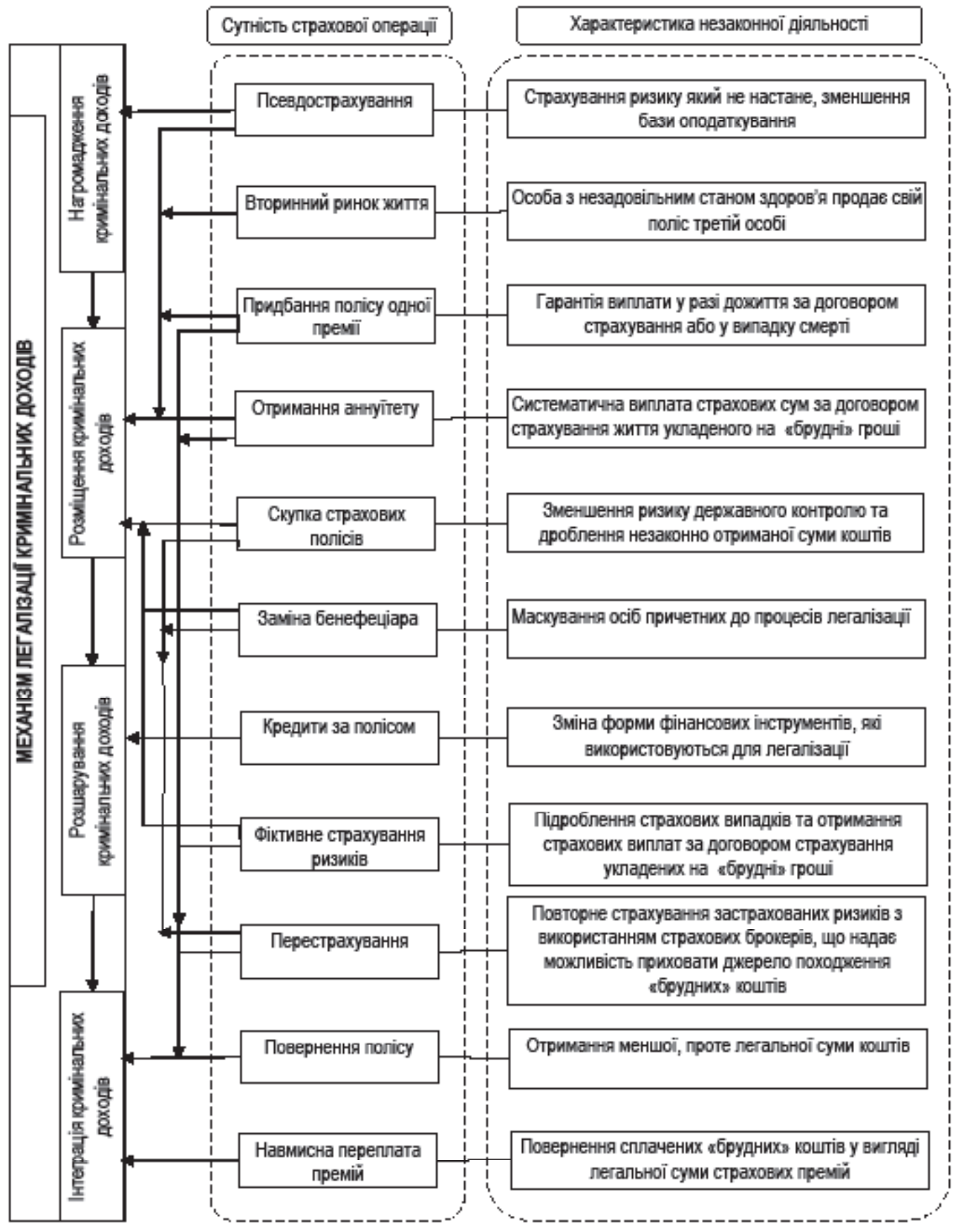

Рис. 1. Механізм легалізації кримінальних доходів

через послуги страхових компаній 
Окремо варто згадати про перестрахування. Перестрахування має значний ризик бути використаним у процесі легалізації незаконних доходів.

За своєю сутністю перестрахування не є страховою операцією. Перестрахування це один з фінансових заходів, який дає змогу перерозподілити страховий фонд ризику між страховими компаніями. При перестрахуванні страховик, який взяв первинний ризик від страхувальника, оцінюючи свої можливості, вирішує розділити його з іншою страховою компанією, передавши їй частину у вторинне розміщення. Так, досить часто національні страхові компанії через значні ризики вимушені перестраховуватись у іноземних страхових компаніях, чим і користуються шахраї.

Однією з основних загроз при перестрахуванні $€$ виведення капіталу та валюти з країни закордон.

Регуляторів за ризиком залучення до легалізації незаконних доходів поділяють перестрахування на дві групи відносно фінансової стійкості компанії-перестраховика. Згідно з таким поділом високий ризик легалізації $є$ у страхових компаній з Польщі, Росії, Латвії, Литви, Естонії й інших країн, діяльність яких пов'язана з офшорними зонами [20].

Отже, з точки зору суб'єктів легалізації незаконних доходів перестрахування цікаве через:

1. Залученість у процес перестрахування значних сум коштів. Часто великий страховий фонд за ризиком розділяється на декілька страхових компаній, що ускладнює та заплутує структуру грошових потоків.

2. Міжнародний характер перестрахового бізнесу. Національним регуляторам складно відстежувати грошові потоки, якщо вони виходять за межі країни.

3. Відсутність єдиної міжнародної регуляторної узгодженості з перестраховими компаніями, які знаходяться в офшорних зонах.

4. Слабкий нагляд за операціями перестрахування у деяких країнах та регіонах.

5. Складність міжнародних структур. У перестрахуванні задіяні різні постачальники капіталу, різні бенефіціари. Окрім цього, може бути ускладнена система власності страхових компаній, які належать до великих конгломеративних структур різних країн.

6. Перестрахувальник здебільшого не знає про особливі умови чи специфічні страхові ризики. При перестрахуванні втрачається принцип «знай свого клієнта» страхувальника, який мав первинний ризик і звернувся до страхової компанії [21].

Показовим був приклад використання перестрахування для відмивання коштів у Великобританії. Перестраховику Великобританіїбулозапропонованоперестрахувати енергетичний ризик від імені закордонного страховика. За домовленістю розмір премії склав 1,5 млн. доларів США. Було узгоджено, що виплата премії включатиме додаткові 10 мільйонів доларів США, які повинні були бути виплачені у вигляді «комісії» страховим брокерам в офшорній зоні. Було також зазначено, що згадані брокери, не брали участь у розміщенні первинного ризику. При виплаті премії платіж склав 21,5 мільйони доларів США. Брокер пояснив, що додаткові 10 мільйонів доларів США були «випадковою» переплатою. Переплату було повернуто на банківський рахунок в офшорній зоні. В даному разі страховик не подавав звіт про підозрілу транзакцію за цією операцією, оскільки законодавство Великобританії не включало загальне 
страхування у перелік операцій, які можуть бути використані для легалізації коштів, отриманих незаконним шляхом. Схему було розкрито під час іншого розслідування.

Іншим прикладом є використання страхової компанії України у ретроцесійних угодах 3 компаніями-нерезидентами з метою заплутування походження коштів і переведення капіталу, окрім цього ліцензія даної компанії на подібні операції була уже припинена. Так, страхова компанія-нерезидент перестрахувала ризик в українській страховій компанії і нарахувала страхову премію у розмірі 2,3 млн. доларів США. Згодом перестраховик уклав договір ретроцесії з третьою компанією-нерезидентом і передала їй відповідний ризик та премію у розмірі 2,3 млн. доларів США. Оскільки дана операція мала ознаки легалізації незаконних доходів та в української страхової компанії була прострочена ліцензія, Національна комісія, що здійснює регулювання у сфері ринків фрінансових послуг змусила 21 страхову компанію розірвати договори перестрахування з цими компаніями [21].

Розглядаючи заходи протидії легалізації доходів, отриманих незаконним шляхом через операції страхових компаній варто зазначити, що, як і для всіх фінансових установ, для сорери страхування необхідним є принцип «знай свого клієнта» та ризикорієнтований підхід. Даний підхід означає, що кожна фрінансова інституція повинна ідентифікувати особу клієнта, його партнерів, особливості діяльності, оцінити ризики співпраці з даним клієнтом та намагатись виявити підозрілу активність з точки зору легалізації незаконних доходів.

Специфічними превентивними заходами як для загального, так і для страхування життя є:

1. Ідентифікація безпосереднього бенефіціара полісу та можливого вигодонабувача увипадкудозволеної законом зміни особи-бенефіціара. Для ідентифікації та подальшої верифрікації в момент виплати необхідно забезпечити отримання максимально повної інформації про клієнта [21].

2. Визнання сфери страхування як такої, через яку відбувається відмивання доходів, отриманих незаконним шляхом.

3. Зменшення кількості можливих посередників.

4. Співпраця з фінансово надійними компаніями та країнами.

5. Формалізація і вивчення можливих схем легалізації незаконних доходів та навчання персоналу протидії легалізації незаконних доходів [22].

Висновки 3 даного дослідження і перспективи подальших розвідок у даному напрямі. Ризик легалізації доходів, отриманих незаконним шляхом через операції страхування $€$ недооціненим і недостатньо дослідженим. Про це свідчить низька кількість повідомлень про підозрілі операції від небанківських фінансових установ та велика кількість вразливих місць у страхуванні для побудови схем легалізації незаконних доходів. Простежується недосконалість регуляторних приписів у цій сфрері. Тому державні регулюючі органи повинні докладати додаткових зусиль для управління та зниження ризику використання операцій страхових компаній.

Загалом, для ринку страхових послуг характерними є недостатня розвиненість наглядових режимів за відмиванням коштів, отриманих незаконним шляхом, складність продукції, її різноманітний асортимент, недосконалість ідентифікації та верифрікації клієнта і значна кількість посередників. Всі зазначені особливості роблять 
сферу страхових послуг привабливою для легалізації доходів, отриманих незаконним шляхом.

Подяка. Ця робота виконана в рамках дослідження за фрінансування Національного фонду досліджень України № 2020.01/0185 «Оптимізація та автоматизація процесів фрінансового моніторингу для зростання інформаційної безпеки України».

\section{תimepamypa}

1. Kendiukhov I., Tvaronaviciene M. Managing innovations in sustainable economic growth. Marketing and Management of Innovations. 2017. №3. P. 33-42. DOI: 10.21272/mmi.2017.3-03.

2. Yarovenko H., Kuzmenko O., Stumpo M. DEA-Analysis Of The Effectiveness Of The Country's Information Security System. SocioEconomic Challenges. 2020. №4(3). P. 142-153. DOI: 10.21272/sec.4(3).142-153.2020

3. Camilleri M. What is the real money laundering risk in life insurance? High-Risk, LowRisk or No Risk - That is the Question. ACAMS Today: The Association of Certified Anti-Money Laundering Specialists. URL: https://www.acamstoday.org/what-isreal-money-laundering-risk-in-life-insurance/ (дата звернення: 01.08.2020)

4. Dmytrov S., Medvid T. An approach to the use of indices-based analysis subject to money laundering and terrorist financing national risk assessment SocioEconomic Challenges. 2017. №1(1). P. 35-47. DOI: 10.21272/sec.2017.1-04.

5. Vieriezubova T., Levchenko V. Openness of the insurance market for foreign entities: methodology and experience of Ukraine. Financial Markets, Institutions and Risks. 2017. №1(2). C. 87-95. DOI: 10.21272/fmir.1(2).87-95.2017

6. Subeh M. A., Boiko A. Modeling efficiency of the State Financial Monitoring Service in the context of counteraction to money laundering and terrorism financing. SocioEconomic Challenges. 2017. №1(2). P. 39-51. DOI: 10.21272/sec.1(2).3951.2017.

7. Sineviciene L., Shkarupa O., Sysoyeva L. Socio-economic and Political Channels for Promoting Innovation as a Basis for Increasing the Economic Security of the State: Comparison of Ukraine and the Countries of the European Union. SocioEconomic Challenges. 2018. №2(2). P. 81-93. DOI: 10.21272/sec.2(2).81-93.2018

8. Levchenko V., Kobzieva T., Boiko A., Shlapko T. Innovations in Assessing the Efficiency of the Instruments for the National Economy De-Shadowing: the State Management Aspect. Marketing and Management of Innovations. 2018. №4. P. 361-371. DOI: 10.21272/mmi.2018.4-31

9. Palienko, M., Lyulyov, O. The impact of social factors on macroeconomic stability: empirical evidence for Ukraine and European Union countries. SocioEconomic Challenges. 2018. 2 Iss. 1. P. 103-116. DOI: 10.21272/sec.2(1).103-116.2018.

10. Яровенко Г.М., Басенко Т.О. Автоматизація аудиту розрахунків з оплати праці. Ефективна економіка. 2012. №3. URL: http://www.economy.nayka.com. ua/?op=1\&z=989

11. МарченкоД.М.,ЯровенкоГ.М.Автоматизованіінформаційнісистемиуправлінняресурс підвищення ефективності успішного контролю підприємств. Сучасні проблеми економіки. 2006. №10. C. 150-159. URL: http://essuir.sumdu.edu.ua/ handle/123456789/52016 
12. Люльов О. В. Формування стратегій розвитку підприємства в умовах незбалансованої економіки. 2011. PhD Thesis. Вид-во СумДУ. URL: https:// essuir.sumdu.edu.ua/handle/123456789/20902 (дата звернення: 01.08.2020)

13. Дані про зареєстровані Державною службою фрінансового моніторингу звіти про фрінансові операції. Державний портал відкритих даних: веб-сайт. URL: $\quad$ https://data.gov.ua/dataset/936c9070-aa05-408b-bc36-c33d3cfd4734/ resource/70c2562e-2b1d-4614-aedd-a0ac9fca55df/download/iiikv_2020.xIsx. (дата звернення: 01.08.2020)

14. Результати діяльності страхових компаній за I квартал 2020 року. Національна комісія, що реалізує державне регулювання у сфрері ринків фрінансових послуг: веб-сайт. URL: https://www.nfp.gov.ua/files/OgliadRinkiv/SK/sk_I_\%202020.pdf. (дата звернення: 01.08.2020)

15. BarhaqA. R., ZakutniaiaA. Central bank transparency: cross-country comprehension (example of inflation reports). Business Ethics and Leadership. 2017. №1(2). P. 4754. DOI: 10.21272/bel.1(2).47-54.2017.

16. Результати діяльності страхових компаній за 2019 рік.Національна комісія, що реалізує державне регулювання у сфері ринків фінансових послуг: веб-сайт. URL: https://www.nfp.gov.ua/files/OgliadRinkiv/SK/sk_2019.pdf. (дата звернення: 01.08.2020).

17. Fomina J., Vynnychenko N. Fiscal transparency: cross-country comparisons. Business Ethics and Leadership. 2017. №1(2). P. 39-46. DOI: 10.21272/bel.1(2).3946.2017.

18. Anti Money Laundering in the Insurance Sector. ComplyAdvantage. URL: https:// complyadvantage.com/knowledgebase/anti-money-laundering-insurance-sector/ (дата звернення: 01.08.2020).

19. Public Consultation on the Draft Risk-based approach Guidance for the Life Insurance Sector. The Financial Action Task Force. URL: http://www.fatf-gafi.org/ media/fatf/documents/Draft\%20RBA\%20Guidance $\% 20$ Life $\% 20$ Insurance $\% 20$ for\%20private\%20sector\%20consultation.docx (дата звернення: 01.08.2020).

20. Актуальні методи і способи легалізації (відмивання) доходів, одержаних незаконним шляхом, та фрінансування тероризму. Державна служба фрінансового моніторингу України: веб-сайт. URL: https://fiu.gov.ua/assets/user files/411/\%D0\%A2\%D0\%B8\%D0\%BF\%D0\%BE\%D0\%BB\%D0\%BE\%D0\%B3\%20 \%D0\%94\%D0\%A1\%D0\%A4\%D0\%9C\%D0\%A3/2012\%2027\%2012_2012.pdf (дата звернення: 01.08.2020)

21. Typology research: Money laundering through private pension funds and the insurance sector. MONEYVAL. URL: https://rm.coe.int/committee-of-experts-onthe-evaluation-of-anti-money-laundering-measur/1680715099 (дата звернення: 01.08.2020)

22. The FATF Recommendations: International standards on combating money laundering ant the financing of terrorism \& proliferation. The Financial Action Task Force. URL: http://www.fatf-gafi.org/media/fatf/documents/recommendations/pdfs/ FATF\%20Recommendations\%202012.pdf (дата звернення: 01.08.2020) 


\section{References}

1. Kendiukhov, I., \& Tvaronaviciene, M. (2017). Managing innovations in sustainable economic growth. Marketing and Management of Innovations, 3, 33-42. Retrieved from: http://doi.org/10.21272/mmi.2017.3-03 [in English].

2. Yarovenko, H., Kuzmenko, O., Stumpo, M. (2020). DEA-Analysis Of The Effectiveness Of The Country's Information Security System. SocioEconomic Challenges, 4 (3), 142-153. Retrieved from: http://doi.org/10.21272/sec.4(3).142153.2020 [in English].

3. Camilleri, M. (2012). What is the real money laundering risk in life insurance? HighRisk, Low-Risk or No Risk - That is the Question. ACAMS Today: The Association of Certified Anti-Money Laundering Specialists. Retrieved from: https://www. acamstoday.org/what-is-real-money-laundering-risk-in-life-insurance/ [in English].

4. Dmytrov, S., Medvid, T. (2017). An approach to the use of indices-based analysis subject to money laundering and terrorist financing national risk assessment SocioEconomic Challenges, 1(1), 35-47. Retrieved from: http://doi.org/10.21272/ sec.2017.1-04 [in English].

5. Vieriezubova, T., Levchenko, V. (2017). Openness of the insurance market for foreign entities: methodology and experience of Ukraine. Financial Markets, Institutions and Risks, 1(2), 87-95. Retrieved from: http://doi.org/10.21272/fmir.1(2).87-95.2017 [in English].

6. Subeh, M. A., Boiko, A. (2017). Modeling efficiency of the State Financial Monitoring Service in the context of counteraction to money laundering and terrorism financing. SocioEconomic Challenges, 1(2), 39-51. Retrieved from: http://doi.org/10.21272/ sec.1(2).39-51.2017 [in English].

7. Sineviciene, L., Shkarupa, O., Sysoyeva, L. (2018). Socio-economic and Political Channels for Promoting Innovation as a Basis for Increasing the Economic Security of the State: Comparison of Ukraine and the Countries of the European Union. SocioEconomic Challenges, 2(2), 81-93. Retrieved from: http://doi.org/10.21272/ sec.2(2).81-93.2018 [in English].

8. Levchenko, V., Kobzieva, T., Boiko, A., \& Shlapko, T. (2018). Innovations in Assessing the Efficiency of the Instruments for the National Economy De-Shadowing: the State Management Aspect. Marketing and Management of Innovations, 4, 361-371. Retrieved from: http://doi.org/10.21272/mmi.2018.4-31 [in English].

9. Palienko, M., Lyulyov, O. (2018). The impact of social factors on macroeconomic stability: empirical evidence for Ukraine and European Union countries. SocioEconomic Challenges. 1(2). P. 103-116. Retrieved from: http://doi. org/10.21272/sec.2(1).103-116.2018 [in English].

10. Yarovenko G.M., Basenko T.O (2012) Avtomatyzatsiia audytu rozrakhunkiv z oplaty pratsi [Automation the audit of wages calculations]. Efficient economy, no. 3. Retrieved from: http://www.economy.nayka.com.ua/?op=1\&z=989 [in Ukrainian].

11. Marchenko D.M., Yarovenko H.M. (2006) Avtomatyzovani informatsiini systemy upravlinnia - resurs pidvyshchennia efektyvnosti vnutrishnoho kontroliu pidpryiemstv [Automated informational systems of management as a resource for enterprise internal control efficiency increase]. Current economic problems, no. 10, 
pp. 150-159. Retrieved from: http://essuir.sumdu.edu.ua/handle/123456789/52016 [in Ukrainian]

12. Lyulyov, O. (2011). Formuvannia stratehii rozvytku pidpryiemstva $v$ umovakh nezbalansovanoi ekonomiky [Formation of enterprise development strategies in an unbalanced economy]. PhD Thesis. Sumy State University. Available at: https:// essuir.sumdu.edu.ua/handle/123456789/20902 [in Ukrainian]

13. Ukrainian state open data web portal. (2020). Data about registered by State Financial Monitoring Service of Ukraine reports on financial transactions. Retrieved from: https://data.gov.ua/dataset/936c9070-aa05-408b-bc36-c33d3cfd4734/ resource/70c2562e-2b1d-4614-aedd-a0ac9fca55df/download/iiikv_2020.xlsx [in Ukrainian]

14. National Commission for State Regulation of Financial Services Markets. (2020). Results of insurance companies activities for the first quarter of 2020 Retrieved from: https://www.nfp.gov.ua/files/OgliadRinkiv/SK/sk_I_\%202020.pdf [in Ukrainian]

15. Barhaq, A. R., Zakutniaia, A. (2017). Central bank transparency: cross-country comprehension (example of inflation reports). Business Ethics and Leadership, 1(2), 47-54. DOI: 10.21272/bel.1(2).47-54.2017 [in English].

16. National Bank of Ukraine. (2020). Review of the non-banking financial sector, October 2020. Retrieved from: https://bank.gov.ua/admin_uploads/article/ Nonbanking_Sector_Review_2020-10.pdf?v=4 [in Ukrainian]

17. Fomina, J., Vynnychenko, N. (2017). Fiscal transparency: cross-country comparisons. Business Ethics and Leadership, 1(2), 39-46. Retrieved from: http:// doi.org/10.21272/bel.1(2).39-46.2017 [in English].

18. Anti Money Laundering in the Insurance Sector. ComplyAdvantage. Retrieved from: https://complyadvantage.com/knowledgebase/anti-money-laundering-insurancesector/ [in English].

19. The Financial Action Task Force. (2018). Public Consultation on the Draft Riskbased approach Guidance for the Life Insurance Sector. Retrieved from: http:// www.fatf-gafi.org/media/fatf/documents/Draft\%20RBA\%20Guidance $\% 20$ Life $\% 20$ Insurance\%20for\%20private\%20sector\%20consultation.docx [in English].

20. State Financial Monitoring Service of Ukraine. (2012). Current methods and ways of legalization (laundering) of proceeds from crime and terrorist financing Retrieved from: https://fiu.gov.ua/assets/userfiles/411/\%D0\%A2\%D0\%B8\%D0\%BF\%D0\% BE\%D0\%BB\%D0\%BE\%D0\%B3\%20\%D0\%94\%D0\%A1\%D0\%A4\%D0\%9C\%D0 \%A3/2012\%2027\%2012_2012.pdf [in Ukrainian]

21. MONEYVAL. (2010). Typology research: Money laundering through private pension funds and the insurance sector. Retrieved from: https://rm.coe.int/committeeof-experts-on-the-evaluation-of-anti-money-laundering-measur/1680715099 [in English].

22. The Financial Action Task Force. (2020). The FATF Recommendations: International standards on combating money laundering ant the financing of terrorism \& proliferation. Retrieved from: http://www.fatf-gafi.org/media/fatf/documents/ recommendations/pdfs/FATF\%20Recommendations\%202012.pdf [in English].

Статтю отримано 4 серпня 2020 р.

Article received August, 4, 2020. 